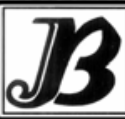

J. bio-sci. 18: $44-48,2010$

ISSN 1023-8654

http://www.banglajol.info/index.php/JBS/index

\title{
MANAGEMENT OF CHICKPEA POD BORER, HELICOVERPA ARMIGERA (HUBNER) USING NEEM SEED EXTRACT AND LAMBDA-CYHALOTHRIN IN HIGH BARIND TRACT
}

\author{
MS Hossain*, MS Islam, MA Salam, MA Hossain ${ }^{1}$, MU Salma² \\ On-Farm Research Division, Barind station, Bangladesh Agricultural Research Institute, Rajshahi \\ ${ }^{1}$ Pulses Research Center, Bangladesh Agricultural Research Institute, Ishurdi, Pabna \\ ${ }^{2}$ Department of Agriculture Extension, Rajshahi
}

\begin{abstract}
Context: Lamda cyhalothrin and neem seed extract can protect chickpea by controlling pod borer Helicoverpa armigera (Hubner).

Objective: To find out the effect of neem seed extract and lambda-cyhalothrin application schedule for the effective and economic management of pod borer attacking chickpea.

Materials and Methods: The experiments were conducted in High Barind Tract of northern Bangladesh with the application of neem seed extract @ $50 \mathrm{~g}^{-1}$ (two and three spraying) and lambda-cyhalothrin. (Karate 2.5 EC) @ $2 \mathrm{ml}^{-1}$ (two and three spraying) and untreated control. The seeds of BARI-Chola 5 chickpea were sown in rows with the spacing of $40 \mathrm{~cm}$. At maturity, all the pods were collected from 10 randomly selected plants from middle rows of each plot. The damaged (bored) and total numbers of pod were counted. The grain yield loss (kg-ha) and percent pod damage were determined. The seed yield of each treatment was converted to $\mathrm{kg}^{\text {-ha }}$.

Results: The lowest pod damage (2.55\%) as well as grain yield loss (34.90 $\mathrm{kg}^{\text {-ha }}$ ) were observed in the treatment where lamda cyhalothrin applied three times at 7 days interval from flowering stage. Chickpea seed yield was maximum (1338 $\mathrm{kg}^{\text {-ha }}$ ) with lamda cyhalothrin sprayed thrice which was identical to sprayed twice (1280 $\left.\mathrm{kg}^{\text {-ha }}\right)$. Neem seed extract showed a marginal performance to control chickpea pod borer. The highest marginal benefit cost ratio (3.19) was recorded from lamda cyhalothrin sprayed twice.

Conclusion: Lamda cyhalothrin double sprayed with 7 days interval from pod formation stage is the best package in managing pod borer in chickpea considering efficacy and profitability.

Keywords: Chickpea, pod borer, pod damage, pesticides, yield.
\end{abstract}

\section{Introduction}

In Bangladesh chickpea is generally grown under rain fed or residual soil moisture conditions in rabi season after harvest of rice during October-March. Among the major pulses grown chickpea ranks fifth in area and production but second in consumption priority. It is a popular pulse crop in High Barind Tract (HBT) in the north-west of Bangladesh (within $24^{\circ} 20^{\prime}-25^{\circ} 15^{\prime} \mathrm{N}, 88^{\circ} 15^{\prime}-88^{\circ} 55^{\prime} \mathrm{E}$ ). Chickpea is estimated to be grown on about 10,000 hectares of land in the HBT and is an important source of income and nutrition for resourcepoor farm families (Musa et al. 2002). The area sown to chickpea in Bangladesh has reduced from $>100,000$ ha during 1980 s to around 15,000 ha in recent years (FAOSTAT 2007). This reduction is primarily attributed to the yield instability caused by pod borer (Rahman et al. 2000). Environmental conditions during the late vegetative and reproductive period for chickpea (February to mid-March) are particularly conducive to pod borer development.

The chickpea has relatively few insect pests but gram pod borer, Helicoverpa armigera (Hubner) Hardwick is the major pest (Lal et al. 1985, Naresh and Malik 1986, Lal 1996). The pod borers inflicted heavy crop losses

* Corresponding author E-mail: shossain72@yahoo.com 
from seedling to maturity. But the losses reached at its peak when the pods appeared (Mehto and Singh 1983, Deka et al. 1989). Lal (1996) reported that the seed yield losses due to $H$. armigera were $75-90 \%$ and in some places the losses were up to $100 \%$. The yield loss in chickpea due to pod borer was reported as 10 to 60 per cent in normal weather conditions, while it was 50 to 100 per cent in favorable weather conditions, particularly in the state where frequent rain and cloudy weather is prevailing during the crop season (Patel 1979). These losses can be reduced by the application of insecticides (Sinha et al. 1983, Singh et al. 1987, Rakesh et al. 1996, Balasubramanian et al. 2001).

In favourable conditions pod borer may cause 90-95 per cent pod damage (Sachan and Katti 1994). The young caterpillar of pod borer skeletonizes the leaves, while grown up caterpillar bores into the pods and feeds on the seeds. Chemical insecticides are generally used in pod borer control due to their effectiveness and easy availability. Recently, $H$. armigera is reported to have developed resistance to many commonly used insecticides (Lande 1992). In past, the best insecticide was reported to be the cypermethrin (Gohokar et al. 1985, Singh et al. 1987, Khan et al. 1993, Jadhav and Suryawanshi 1998) and endosulfan (Chaudary et al. 1980, Rizvi et al. 1986). Phokela et al. (1990) observed a tendency of increased resistance to cypermethrin in the population of $H$. armigera. Moderate to high levels of resistance to cypermethrin and moderate resistance to endosulfan were recorded in field populations of $H$. armigera (Ahmad et al. 1995).

In many trails lamda cyhalothrin performed well to control pod borer. Farmers generally sprayed insecticides at full podding or pod maturing stage when full-grown pod borer are visible on the plant with boring pods. As a result the grown up pod borers are not killed instead it creates environmental pollution. These led to the present experiments.

\section{Materials and Methods}

The experiments were conducted in the farmer's field at Farming System Research and Development (FSRD) site, Bangladesh Agricultural Research Institute (BARI), Kadamshahar, Godagari, Rajshahi during Rabi season of 2008-2009 in the HBT. Application of neem seed extract and lambda-cyhalothrin considered as treatments of the experiments which were: $\mathrm{T}_{1}=$ spraying of neem seed extract @ $50 \mathrm{~g}^{-1}$ (two sprayings at 7 days interval starting from pod formation stage), $\mathrm{T}_{2}=$ spraying of lamda cyhalothrin (Karate $2.5 \mathrm{EC} @ 2 \mathrm{ml}^{-}$ 1) (two sprayings at 7 days interval starting from pod formation stage), $T_{3}=$ spraying of neem seed extract 50 $\mathrm{g}^{-1}$ (three spraying at 7 days interval from flowering stage), $\mathrm{T}_{4}=$ spraying of lamda cyhalothrin (Karate $2.5 \mathrm{EC}$ @ $2 \mathrm{ml}^{-1}$ ) (three sprayings at 7 days interval starting from flowering stage), $T_{5}=$ untreated control. It was laid out in randomized complete block design with six dispersed replications. The land was fertilized with 12-2017-10-1 N-P-K-S-B kg/ha (BARC 2005) in the form of urea, triple super phosphate, muriate of potash, gypsum and boric acid, respectively. All fertilizers were applied as basal at the final land preparation. The seeds of BARI-Chola 5 chickpea were sown in rows with the spacing of $40 \mathrm{~cm} @ 50 \mathrm{~kg}^{\text {-ha }}$ ranging from 23-25 October 2008. The unit plot size was $3 \mathrm{~m} \times 4 \mathrm{~m}$ with a distance of $100 \mathrm{~cm}$ between the plots and $150 \mathrm{~cm}$ between the replications. The spraying was done by Knapsck hand sprayer as per treatments. At maturity, all the pods were collected from 10 randomly selected plants from middle rows of each plot and examined. The damaged (bored) and total numbers of pods were counted and the percent pod damage was determined.

The grain yield loss ( $\mathrm{kg}^{\text {-ha }}$ ) due to pod borer damage of each treatment was calculated according to Hossain et al. (1999). Plants of middle four rows avoiding border rows of each plot comprising $4.8 \mathrm{~m}^{2}(1.6 \mathrm{~m} \times 3 \mathrm{~m}$ ) area was harvested. The pods were then threshed; grains were cleaned and dried in the bright sunshine. The seed yield of selected area was converted to $\mathrm{kg}^{-\mathrm{ha}}$. The experimental data were analyzed by MSTAT-C software. The percent data were subjected to square root transformation for statistical analysis. Mean comparisons for treatment parameters were compared using Duncan's Multiple Range Test (Steel and Torrie 
$1960)$ at $5 \%$ level of significance. The economic analysis was done for gross return, gross margin and marginal benefit cost ratio (MBCR) for different treatments following the method suggested by CIMMYT (1988). For calculating income and benefit the following market prices were used: Karate $2.5 \mathrm{EC}=$ Tk.100.00-100ml, Neem seed $=$ Tk. 50.00-kg and Chickpea $=$ Tk. 40.00-kg, Labour wage for spraying pesticides $=$ Tk.150/day/labour (work $8 \mathrm{~h} /$ day).

\section{Results}

Effect on pod damage and yield loss: Neem seed extract and lambda-cyhalothrin reduced pod borer damage significantly (Table 1). Significantly the lowest pod damage (2.55\%) and grain yield loss (34.90 $\mathrm{kg}^{\text {ha }}$ ) were observed in the treatment where lambda-cyhalothrin was applied thrice at 7 days interval from flowering stage. The next highest pod damage (4.23\%) and yield loss (56.39 $\mathrm{kg}$-ha) were found in lambda-cyhalothrin sprayed double at 7 days interval from pod formation stage. The highest pod damage (10.66\%) and seed yield loss (124.71 kg-ha) were recorded in untreated crop. The highest number of pods/plant (43.20) was found in the lambda-cyhalothrin sprayed three times which was statistically identical to two applications (41.32) and the lowest was in untreated control (32.40). This might be due to its high toxicity with fast acting activities that produced quick knock down action to pod borer resulted in the lowest pod damage and also produced highest number of pods/plant. Due to highest pod borer infestation, some twigs, flowers and pods might completely damaged in untreated control resulted highest pod damage and lowest number of $\operatorname{pod} /$ plant.

Yield, gross return, gross margin and marginal benefit cost ratio: Yield of chickpea varied significantly with the level of pod borer damage depending on efficacy of neem seed extract and lambda-cyhalothrin (Table 1). Significantly the highest yield (1338 $\mathrm{kg}^{\text {-ha }}$ ) was obtained from lambda-cyhalothrin applied three times which was statistically identical to sprayed two times (1280 kg-ha) and the lowest (1049 $\left.\mathrm{kg}^{\text {-ha }}\right)$ was in untreated control. Spraying neem seed extract provided statistically identical yield to untreated control. Yield increased was $27.58 \%$ and $22.03 \%$ over untreated control in lambda-cyhalothrin sprayed thrice and twice, respectively (Table 1). Neem seed extract was found moderately effective for controlling the pod borer. Lower pod borer damage and higher number of pod/plant were found in lambda-cyhalothrin spraying contributed to higher yield of chickpea.

Table 1. Effect of neem seed extract and lambda-cyhalothrin on pod damage and yield loss of chickpea

\begin{tabular}{|c|c|c|c|c|c|c|c|c|c|c|}
\hline Treatments & $\begin{array}{l}\text { No. of } \\
\text { spray }\end{array}$ & Pods/ plant & $\begin{array}{c}\text { Pod damage } \\
(\%)\end{array}$ & $\begin{array}{l}\text { Yield loss } \\
\left(\mathrm{kg}^{-\mathrm{ha}}\right)\end{array}$ & $\begin{array}{l}\text { Yield } \\
(\mathrm{kg} / \mathrm{ha})\end{array}$ & $\begin{array}{c}\text { Yield } \\
\text { increase } \\
\text { over control } \\
(\%)\end{array}$ & $\begin{array}{l}\text { Gross } \\
\text { return } \\
\text { (Tk./ha) }\end{array}$ & $\begin{array}{l}\text { Variable } \\
\text { cost* }^{*} \\
(\mathrm{Tk} . / \mathrm{ha})\end{array}$ & $\begin{array}{c}\text { Gross } \\
\text { margin } \\
\text { (Tk./ha) }\end{array}$ & $\begin{array}{c}\text { Marginal } \\
\text { benefit cost } \\
\text { ratio (MBCR) }\end{array}$ \\
\hline$\overline{T_{1}: \text { Neem seed extract }}$ & 2 & $38.05 b$ & $7.19 \mathrm{~b}(2.68)$ & $84.15 b$ & $1087 \mathrm{C}$ & 3.67 & 43490 & 3400 & 40090 & 0.45 \\
\hline $\mathrm{T}_{2}$ : Karate $2.5 \mathrm{EC}$ & 2 & $41.32 a b$ & $4.23 \mathrm{~d}(2.06)$ & $56.39 \mathrm{C}$ & $1280 a b$ & 22.03 & 51190 & 2900 & 48290 & 3.19 \\
\hline $\mathrm{T}_{3}:$ Neem seed extract & 3 & $38.82 \mathrm{~b}$ & 5.53 c (2.35) & $66.99 \mathrm{c}$ & 1146 bc & 9.23 & 45820 & 5000 & 40820 & 0.77 \\
\hline $\mathrm{T}_{4}:$ Karate $2.5 \mathrm{EC}$ & 3 & $43.20 \mathrm{a}$ & 2.55 e $(1.60)$ & $34.90 \mathrm{~d}$ & $1338 \mathrm{a}$ & 27.58 & 53520 & 4350 & 49170 & 2.66 \\
\hline$T_{5}$ : Untreated control & - & $32.40 \mathrm{c}$ & $10.66 \mathrm{a}(3.27)$ & $124.71 \mathrm{a}$ & $1049 \mathrm{c}$ & - & 41950 & - & 41950 & - \\
\hline $\operatorname{LSD}(0.05)$ & & 3.93 & 0.22 & 15.82 & 141.00 & - & - & - & - & - \\
\hline CV $(\%)$ & & 4.70 & 4.18 & 11.99 & 5.53 & - & - & - & - & - \\
\hline
\end{tabular}

The gross return, gross MBCR cost ratio varied depending on cost of pesticide application (Table 1). The highest gross return (Tk.53,520-ha) was recorded from lambda-cyhalothrin sprayed three times followed by sprayed two times (Tk.51,190-ha) and the lowest (Tk.41,950-ha) was in untreated control. On the other hand maximum variable cost (Tk.5,000-ha) was calculated from neem seed extract sprayed thrice. The MBCR of pesticide application revealed the highest monetary benefit from lambda-cyhalothrin two applications whose 
MBCR was 3.19. The lowest MBCR (0.45) was found when the crop sprayed three applications with neem seed extract. This variation was attributed due to the variation of seed yield of chickpea along with low cost involvement in lambda-cyhalothrin application.

\section{Discussion}

A field trial was conducted in India during the summer to evaluate the efficacy of lambda-cyhalothrin against the pod borers $\mathrm{H}$. armigera of red gram (Cajanus cajan). Lambda-cyhalothrin was sprayed 3 times at 15-day intervals at 10,20 or $40 \mathrm{~g}$ a.i. -ha. Percentage pod damage by pod borer was 5.1 in the $40 \mathrm{~g}$ a.i. -ha treatment. The highest yield (1506 kg-ha) was recorded in this treatment (Mathirajan et al. 2000). Singh et al. (1985) observed that percentage pod damage due to $\mathrm{H}$. armigera was much less in pigeon pea plot treated with ethanolic extract neem seed kernel (2\%). Visalakshimi et al. (2005) reported that application of neem effectively reduced the oviposition of $H$. armigera throughout the crop period. Reddy et al. (2010) studied the efficacy of common insecticides viz., neem seed kernel extract (NSKE), HaNPV, Endosulfan were tested alone and in combination against gram pod borer, H. armigra in chickpea. Result showed that larval reduction was highest with NSKE 1.66\% + HaNPV 250LE/ha + Endosulfan $0.023 \%$ followed by NSKE $1.66 \%+$ Endosulfan $0.023 \%$, NSKE $2.5 \%$ + HaNPV 250LE sprayed twice at 15 days interval, respectively.

\section{Conclusion}

Lambda-cyhalothrin 2.5 EC @ $2 \mathrm{mH}^{-1}$ sprayed two times at 7 days intervals from pod formation stage determined to be the best package in managing pod borer in chickpea considering efficacy and profitability in HBT.

\section{Acknowledgement}

The authors are grateful to Bangladesh Agricultural Research Institute (BARI) for providing financial and logistic support to conduct the experiment.

\section{References}

Ahmad M, Arif Ml, Ahmad Z. 1995. Monitoring insecticide resistance of Helicoverpa armigera (Lepidoptera: Noctuidae) in Pakistan. J Econ Entomol 88, 771-776

Balasubramanian G, Babu PCS, Manjula TR. 2001. Efficacy of Spicturin against Helicoverpa armigera Hubner on chickpea (Cicer arietinum L.). Madras Agric J 88, 336-338

BARC (Bangladesh Agricultural Research Council). 2005. Fertilizer Recommendation Guide. Bangladesh Agril. Res. Coun., Farmgate, Dhaka 1215. pp. 1-260.

Chaudhary JP, Yadav LS, Rustogi KB. 1980. Chemical control of gram pod borer, Heliothis armigera Hubner and semi-loopers, Plusia spp. on gram, Cicer arietinum L. Haryana Agri Univ J Res 10, 324-328

CIMMYT. 1988. From Agronomic Data to Farmer Recommendations: An Economic Traning Manual. International Maize and Wheat Improvement Centre, Mexico, D.F. p.79.

Deka NK, Prasad D, Chand P. 1989. Plant growth, Heliothis incidence and grain yield of chickpea as affected by date of sowing. J Res $1,161-8$

FAOSTAT. 2007. http://faostat.fao.org/site/340/DesktopDefault.aspx?PageID=340. FAO Statistics Division 2007, 18 April 2007.

Gohokar RT, Thakre SM, Borle MM. 1985. Chemical control of gram pod borer (Heliothis armigera Hubner) by different synthetic pyrethroids and insecticides. Pesticides 19, 39-40

Hossain MA, Rahman MM, Islam MN. 1999. Effect of intercropping and sowing dates on the incidence of pod borer, Helicoverpa armigera, yield and yield loss of chickpea. Ann. Bangladesh Agric 9(1): 57-64.

Jadhav RS, Suryawanshi DS. 1998. Chemical control of Helicoverpa armigera (Hubner) on chickpea. J Maharashtra Agric Univ 23, 83-84

Khan MM, Rustamani MA, Talpur MA, Balouch HB, Chhutto, AB. 1993. Efficacy of different insecticides against Heliothis armigera (Hub.) on gram. Pakistan J Zool 25, 117-119 
Lal OP. 1996. An outbreak of pod borer, Heliothis armigera (Hubner) on chickpea in Eastern Uttar Pradesh, India. J Entmol Res 20, 179-181

Lal SS, Yadava CP, Dias CAR. 1985. Assessment of crop losses in chickpea caused by Heliothis armigera. FAO Plant Prot Bull 33, 27-35

Lande SS. 1992. Susceptibility of Helicoverpa armigera ( $\mathrm{Hb}$.) to conventional insecticides. Unpublished M Sc Thesis submitted to P.K.V., Akola.

Mathirajan VG, Natarajan K, Kuttalam S, Chadrasekaran S, Regupathy A. 2000. Evaluation of lambda-cyhalothrin for the control of pod borers on red gram. Annals Plant Protection Sciences 8(2), 246-247

Mehto DN, Singh KM. 1983. Succession of insect pests in chickpea, Cicer arietinum Linn. Indian J Entomol 45, 377-383

Musa AM, Jonansen C, Ali MY. 2002. Promotion of chickpea in the High Barind Tract of Bangladesh, In: Bakr MA, Siddique KHM, Johansen C eds. Integrated management of botrytis grey mould of chickpea in Bangladesh and Qustralia, summary proceedings of a Project Inception Workshop, 1-2 June 2002, Bangladesh Agricultural Research Institute (BARI), Joydebpur, Gazipur, Bangladesh; and Centre for Legumes in Mediterrannean Agriculture, The Unibersity of Western Australia, Crawley, Western Australia 6009, Australia.pp. 94-105.

Naresh JS, Malik VS. 1986. Observations on the insect pests of chickpea (Cicer arietinum L.) in Haryana. Bull Entomol 27, 75-77

Patel RK. 1979. Unusual outbreak of gram pod borer on gram in Madhya Pradesh. Sci Cult 45 (1), 335-336

Phokela A, Dhingra S, Sinha SN, Mehrotra KN. 1990. Pyrethroid resistance in Heliothis armigera Hubner: Development of resistance in field. Pestic Res J 2, 28-30

Rahman MM, Bakr MA, Mia MF, Idris KM, Gowda CLL, Kumar J, Deb UK, Malek MA, Sobhan A. 2000. Legumes in Bangldesh. In: Johansen C, Duxbury JM, Virmani, SM, Gowda CLL, Pande S, Joshi PK. (eds.), Legumes in Rice and Wheat Cropping Systems of the Indo-Gangetic Plain-Constraints and Opportunities. International Crops Research Institute for the Semi-Arid Tropics, Patancheru, AP 502 324, India; and Cornell University, Ithaca, New York, USA, pp. 5-34.

Rakesh R, Paras N, Rai R, Nath P. 1996. Evaluation of some insecticides for the management of the pod-borer, Helicoverpa armigera infesting gram, Cicer arietinum. Ann Plant Prot Sci 4, 154-159

Reddy V, Anandhi P, Elamathi S, Simon S. 2010. Efficacy of some common insecticides for the management of pod borer Helicoverpa armigera (Hubner) on chick pea at field condition. Legume Res 33 (1), 74-75

Rizvi SMA, Chandhary MB, Pandey V, Upadhyay VK. 1986. Efficacy and economics of some insecticides in the management of Heliothis armigera Hubner. Indian J Plant Prot 14, 47-50

Sachan JN, Katti G. 1994. Integrated Pest Management. Proceeding of International Symposium on Pulses Research, April 2-6, IARI, New Delhi, India. pp. 23-30.

Singh HM, Singh R, Rizvi SMA. 1987. Screening of synthetic pyrethroids against Heliothis armigera attacking chickpea. Narendra Deva J Agric Res 2, 140-143

Singh RP, Singh Y, Singh SP. 1985. Field evaluation of neem (Azadirachta inadica A. Juss) seed kernel extracts against the pod borers of pigeon pea, (Cajanus cajan L.) Millsp. Indian J Entomol 47(1), 111-112

Sinha MM, Yazdani SS, Kumar A, Lal K. 1983. Relative efficacy of different spray formulations against gram pod borer. Pesticides 17, 33-34

Steel RGD, Torrie JH. 1960. Principles and Procedures of Statistics, pp. 107-109. McGraw-Hill Book. Co. Inc., New York.

Visalakshmi V, Ranga GV, Arjuna Rao P. 2005. Integrated pest management strategy against Helicoverpa armigera in chickpea. Indian J Plant Prot 33 (1), 17-22 